\title{
nature
}

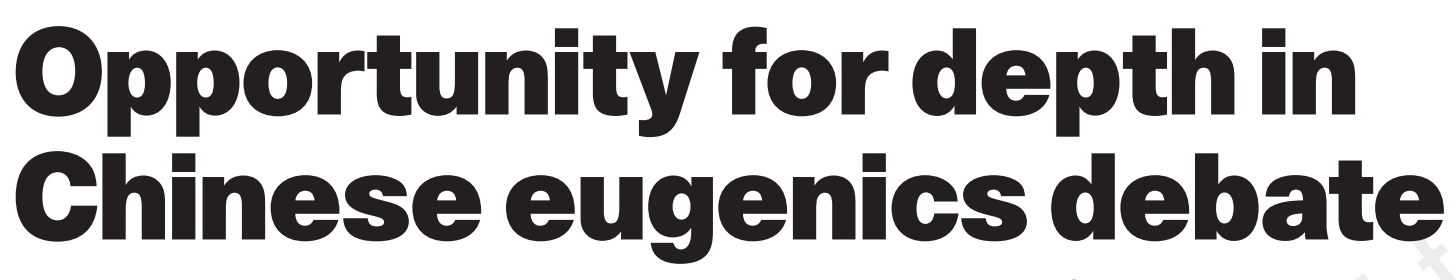

A meeting in Beifing should provide a welcome opportunity to move forward in debates about the ethics and science of eugenics. Western scientists and their hosts should make the most of it.

T he publisher HarperCollins and its proprietor Rupert Murdoch have in the past two weeks been humiliatingly exposed in their disposing of the memoirs of the ex-governor of Hong Kong and arch-China-critic Chris Patten. It is ironic that the same publisher was responsible for a book, Wild Swans by Jung Chang, which, in its matter-of-fact and compellingly detailed account of the experiences of three generations of women in China, presents as devastating (and widely read) an indictment of that country's recent history as any Westerner could hope to muster. But the book also underlines the circumstances of many Chinese people which have led them to support the communist regime and to continue to do so. It is against that context of widespread poverty and technological backwardness, combined with cultural and even spiritual perceptions of the individual quite different to traditional Western values, that Chinese domestic policies need to be considered.

One policy that has caused much debate is the infant and maternal health law which came into effect in 1995. Introduced in the face of concern about a high "burden of disability", it contains measures that will certainly reinforce the already significant improvement in the - by Western standards - calamitous state of health of large numbers of the population. But it contains articles that refer to the need to consider prevention of marriages, enforced contraception and abortions in the face of "serious hereditary diseases" in adults - in particular, autosomal dominant diseases that cannot be detected prenatally.

To some Chinese, at least, the law appears to represent a wholly positive step. One member of the Chinese Academy of Sciences has defended it thus: "China now has a population of 20 million handicapped....Without effective action, China will have an even larger population with serious hereditary diseases and it will naturally impose a grave social problem as regards their livelihood, social and cultural development as a whole and even the quality of the whole population."

In contrast, the law is seen by many in the West as an unacceptable application of eugenics. Coming hard on the heels of a recent Chinese track-record of brutal suppression of dissent, it has caused considerable and legitimate heart-searching in the research community. An event initially threatened by such concerns, the 18th International Congress on Genetics organized by the International Genetics Federation (IGF) - a federation of learned societies - is nevertheless taking place in Beijing on 10-15 August this year (see www.igf.org for details and deadlines). In order to meet the concerns of participants about the implications of the new law, and to encourage discussion of the consequences within the Chinese research community, it includes a session on the ethics and science of eugenics. But some Western scientists who would otherwise have attended will stay away given this background. One society - Britain's Genetical Society is boycotting the meeting, not wishing to be seen as endorsing the law.

That is regrettable. Much needs to be aired in public about differing perceptions of disability between East and West, about the practicalities of screening for genetically complex diseases, about the opportunities of and obstacles to gene therapy, and about the increasingly probable development of germline manipulation - a technology that may well be more enthusiastically embraced in East Asia than in the West, given statements by Asian bioethicists. In short, there is a need for breadth and depth in appreciating the issues, to which this meeting can contribute.

The session on eugenics may turn out to be a fig-leaf rather than an opportunity for genuine discussion. If China wants to develop its reputation as a modern scientific nation, then it has a responsibility to work with the IGF to ensure that this does not happen. It would be a sorry thing to see a much-needed dialogue undermined while, altogether less challengingly, Rupert Murdoch's Star TV spreads into as many Chinese homes as can receive it.

\section{Gleam in Korean gloom}

\section{South Korea's president has taken a bold first step by strengthening the science ministry, but problems abound.}

$D$ resic

resident Kim Dae-Jung has given a moment of cheer to Korean scientists amid the gloom of economic crisis. His move to upgrade the status of the Ministry of Science and Technology (MOST) to a full-blooded ministry with equal status to its powerful neighbours, such as that of trade and industry, is long overdue (see page 112). With stronger teeth, MOST must now achieve better coordination of policy and funding across the various sciencerelated ministries. With prudence, the move should also lead to more money for some of MOST's more innovative funding mechanisms, such as the centre-of-excellence programme of the Korean Science and Engineering Foundation and the new Creative Research Initiative (see Nature 391, 625; 1998), both of which provide substantial long-term grants for Korea's best researchers in universities and government institutes.

But much remains to be done. The universities, of which there are well over a hundred, have a multitude of science and engineering departments in which talented and not-so-talented scientists and engineers languish. The whole university research system, which is administered primarily by the conservatively minded education ministry, needs to be overhauled through processes of research assessment (still rare in Korea) and more targeted funding of the type provided by MOST. The economic crisis may help this process. Several lower-rank universities are said to be on the brink of financial collapse having invested too heavily in new campuses and other facilities. This may encourage the government to focus its research funding more selectively and wisely within the universities. 